\title{
Removal of Foreign Body (Denture) in Esophagus with Rigid Esophagoscope
}

\author{
Fachzi Fitri, Hidayatul Fitria
}

\begin{abstract}
Abstrak
Latar Belakang: Seiring dengan meningkatnya pemakaian gigi palsu, kasus tertelan gigi palsu juga meningkat. Gigi palsu yang tertelan harus segera dikeluarkan, karena bila terlambat akan meningkatkan risiko terjadinya komplikasi. Tujuan: Laporan kasus ini dimaksudkan untuk menjelaskan gambaran klinik, diagnosis dan penatalaksanaan benda asing gigi palsu di esofagus. Kasus: Seorang laki-laki 31 tahun dengan benda asing gigi palsu di esofagus. Penatalaksanaan: Esofagoskopi kaku dilakukan untuk pengangkatan gigi palsu Kesimpulan: Diagnosis benda asing gigi palsu di esofagus ditegakkan berdasarkan anamnesis, pemeriksaan fisik, pemeriksaan radiologis dan pemeriksaan esofagoskopi. Esofagoskopi sering dilakukan dalam pengangkatan benda asing di esofagus.
\end{abstract}

Kata kunci: Benda asing, gigi palsu, esofagoskop kaku

\begin{abstract}
Background: Increasing in the number of people wearing denture, a proportionate increase in the incidence of esophageal impacted denture. Impacted denture has to be removed soon since the diagnosis has been made, because the delay can increase the complication. Purpose: To describe the clinical finding, diagnostic tool and management of foreign body (denture) in esophagus. Case: A 31 years old man with impacted denture in esophagus. Management: Rigid esophagoscopy was performed to remove the denture. Conclusion: Removal of impacted denture in esophagus was diagnosed based on anamnesis, physical examination, radiological finding and esophagoscopy. Esophagoscopy is often performed in removal of impacted denture in esophagus.
\end{abstract}

Keywords: Foreign body, denture, rigid esophagoscope

Affiliasi penulis : Bagian Telinga Hidung Tenggorok Bedah Kepala LeherFakultas Kedokteran Universitas Andalas/RSUP Dr. M. Djamil Padang

Korespondensi : Fachzi Fitri, Bagian Telinga Hidung Tenggorok Bedah Kepala LeherFakultas Kedokteran Universitas Andalas/RSUP Dr. M. Djamil Padang

\section{Introduction}

The tooth contributes to the esthetic appearance of the face. Replacing missing teeth, apart from improving facial esthetics, makes eating a more pleasant experience and enhances clarity of speech. As a result of tooth loss due to caries and periodontal disease lead to an increase in the number of people wearing dentures and thus, a proportionate increase in the incidence of esophageal impacted dentures.

Impacted acrylic dentures in the esophagus seen and treated in the ORL-UCH over a 16-year (January 1987-December 2002) was reported by Nwaorgu fifty seven cases with male and female ratio 2.7:1. The age of the patients ranged between 23-77 years, with a mean of 48.7 years. The mean duration before presentation was four days with a range of one to 15 days. However, the majority (54.5\%) presented within 48 hours of impaction. ${ }^{1}$

Adhikari ${ }^{2}$ demonstrated about $51.5 \%$ cases of foreign body in adult, the swallowed denture cases were $2.4 \%$. At M. Djamil hospital, in the middle year of 2007 until September 2010 was reported about thirteen cases of swallowed denture. The youngest age was 18 years old and the oldest one was 70 years old. The incidence was higher in male than female.
The most common site of all these dentures was at cricopharyngeal junction (51.9\%), followed by esophagus $(46.8 \%){ }^{2}$ Nwaorgu ${ }^{1}$ reported a majority of the dentures fourteen $(63.6 \%)$ were impacted in the upper esophagus (between the crico-pharyngeus and the thoracic inlet), while seven (31.8\%) and one (4.5\%) were impacted in the upper thorax and lower esophagus, respectively. An impacted denture was diagnosed based on anamnesis, clinical sign and radiological findings.

The physical findings and symptoms of aspirations caused by foreign body was vary, depending on the location, tissue reaction, the size, the form, and the constitution of the object. ${ }^{3}$ Impacted foreign bodies in the esophagus can easily cause mucosal ulceration, inflammation or even infections and can also result in various fatal complications such as para or retroesophageal abscess, mediastinitis, empyema, perforation or even esophago-aortic fistula. ${ }^{4}$

The main symptoms of patients complained of were difficulty in swallowing, acute onset of pain, dysphagia and excessive salivation. ${ }^{4}$ It is usually presented with dysphagia or inability to swallowed the saliva in children, and is often mistaken from odynophagia, symptoms such as pain in the retrosternal region and the back, angina pectoris, and cardiovascular injuries. Additional findings may be present in case of complications. ${ }^{3}$

Physical examination may be normal in as many as $90 \%$ of patients with esophageal impaction. Rare findings on physical examination include; fever, pharyngeal erythema, palatal abrasion and 
subcutaneous emphysema suggestive of esophageal perforation. ${ }^{5}$

Accurate radiological localization of the site of impaction preoperatively, however, may be difficult even with the use of contrast medium. This is because of most dentures are made of acrylic resins that are radiolucent. It may be possible to observe air entrapment around the denture or increase in the prevertebral soft tissues on plain x-rays, especially when a local inflammatory response has set in. ${ }^{1}$ If no foreign body was identified and the patient remained symptomatic, endoscopy was performed. ${ }^{4}$

The best modality of foreign body removal has been a subject of much controversy for years. ${ }^{4,6}$ The choice of treatment is influenced by many factors, such as the patient's age and clinical condition, the size and shape of the ingested foreign body, the anatomic location and the skills of the physician.

Endoscopy is currently the most commonly used method for removal. The greatest advantage is the one of direct examination and evaluation of the degree of esophageal injury inflicting by the foreign body and search for multiple ones. Rigid esophagoscope had been the primary tool up to 1957 when Hirschowitz constructed the first flexible fiberoptic endoscopy employed by the gastroenterologists for investigating patients with complaints involving the upper digestive tract. ${ }^{4}$

Today, either rigid or flexible endoscopy performed under general anesthesia or conscious sedation respectively, are considered to be safe and effective methods in experienced hands. Of course, for both, there are some advantages and disadvantages. On the one hand, flexible endoscopy can be costeffective because it is performed on an outpatient basis without general anesthesia, but on the other hand, when sharp or penetrating foreign bodies are in question, rigid endoscopy is required. ${ }^{4}$

The wide lumen of the rigid instrument is great help in manipulating the foreign body and extracting it, and believes that this should be the instrument of choice. This idea is not isolated and has been suggested by several authors. Extraction of foreign body requires special attention and experience. ${ }^{6} \quad$ Some foreign bodies may have to be drawn, sometimes only partially, into the lumen of the rigid esophagoscope, to enable their manipulation and extraction while protecting the esophageal mucosa., This protection is not possible with the flexible instrument. $^{6}$

Complications of rigid esophagoscope are often injury of mouth, tongue, teeth, palate and rare esophagus perforation. Esophagus perforation commonly occur in cricopharyngeal level. ${ }^{7}$ Perforations may result in death. ${ }^{6}$

If the foreign bodies are not removed at the earliest, they can cause erosion, perforation, abscess or mediastinitis. ${ }^{2}$ One of the early symptoms of mediastinitis is supraclavicular subcutaneous emphysema. ${ }^{3}$ The incidence of such complications occurs even after the removal of foreign body which is often due to anesthesia, or due to delayed presentation. However other studies showed complications like esophageal perforation, esophagoaortic fistula, empyema thoracis, mediastinitis and lung abscess. ${ }^{2}$

\section{Case Report}

At $08.10 \mathrm{am}$, on September $14^{\text {th }} 2010,31$ years-old man with MR 708623 applied to the emergency department M. Djamil hospital with chief complaint swallowed of denture since 5 hours before admission. Patient was coughed repeated then the denture was freed and swallowed. No history of chocking. The denture has a wire in acrylic part. Pain and difficulty in swallowing were also suffered after incident. Exceeded salivation was presented. He tried to pull out the denture by his finger but not succeeded. Saliva with bloody show was appearance. Fever, difficulty in breathing, vomiting were not found.

On physical examination, general condition was moderately ill, composmentis cooperative, and temperature $36.8^{\circ} \mathrm{C}$.

On ENT examination revealed no abnormality was detected in the ear and nose. Inspection of throat was obtained, pharyngeal arch was symmetric, tonsil $\mathrm{T} 1-\mathrm{T} 1$, there was echimosis at right tonsil and both of peritonsil regions. Indirect laryngos-cope found epiglottis was not hyperemic; standing secretion at piriformis sinus was presented. We diagnosed by foreign body (denture) at esophagus. Our planning was esophagoscopy and removal of foreign body under general anesthesia. Laboratory finding were haemoglobin $15.4 \mathrm{~g} / \mathrm{dl}$, leucocytes $13,500 / \mathrm{mm}^{3}$, thrombocytes $208,000 / \mathrm{mm}^{3}$, haematocrytes $46 \%$, PT/APTT 10.3"/39.0" and random blood sugar 125 $\mathrm{mg} / \mathrm{dl}$.

Radiology finding was seen radiopaque appearance at level cervical VI-VII. Patient was gave therapy ceftriaxon inj $2 \times 1$ gram, dexamethasone inj $3 \times 5 \mathrm{mg}$ and ranitidine inj $2 \times 1$ ampul.

Cervical radiograph was undertaken again before esophagoscopy. The location of impaction denture was same as previous radiograph.

Esophagoscopy date of operation was performed under general anesthesia at $10.50 \mathrm{am}$, on September, 14 $4^{\text {th }}$ 2010. Patient was laid down on operation table. Aseptic and antiseptic procedure was performed in the operating field.

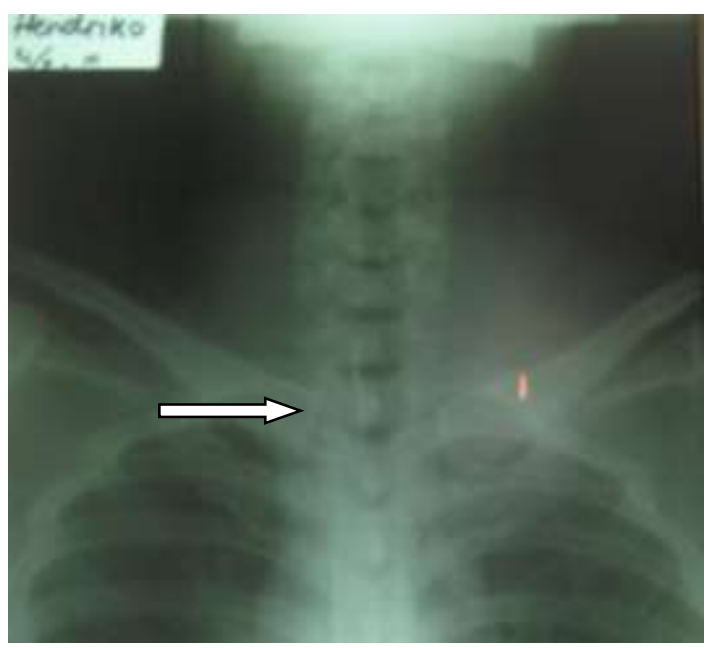

Fig 1. Cervical anteroposterior radiograph on September, $14^{\text {th }} 2010$ at $08.50 \mathrm{am}$. 


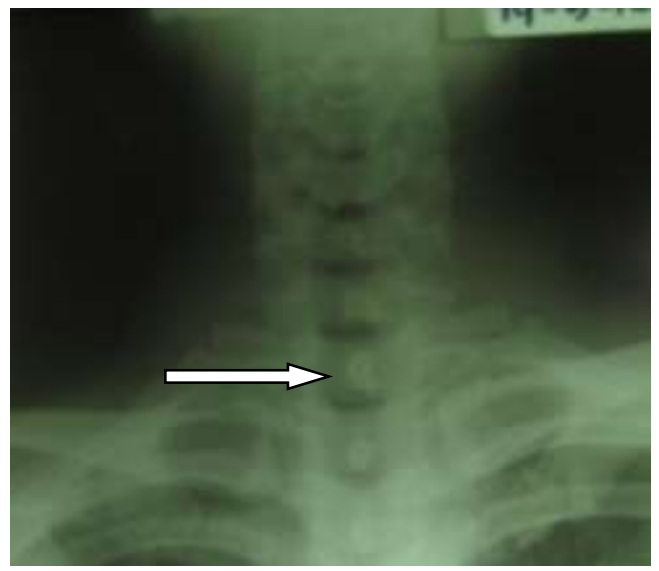

Fig 2. Cervical anteroposterior radiograph on September, $14^{\text {th }} 2010$ at 10.15 am

Esophagoscope with $30 \mathrm{~cm}$ in length, 10x14 $\mathrm{mm}$ in size was hold with left hand like holding billiard stick, middle and ring finger opened the mouth and attached to incisivus. The mean while forefinger and ring finger grasped the distal of esophagoscope.

The left hand shoved esophagoscope bit by bit, and the right hand supported the proximal esophagoscope. Patient was laid down with the head was buttressed.

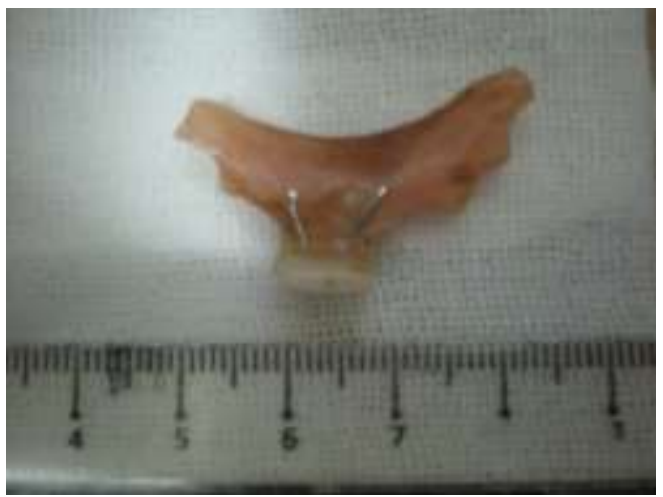

Fig 3. Denture photograph

Esophagoscope was inserted into the mouth vertically trough the right side and the head was in flexi on position. Esophagoscope was brought in the right side of tongue until uvula and posterior pharynx were visible, thumb of left hand moved a tip of esophagoscope into right arytenoids, piriformis sinus, and introitus of esophagus, and the tip of esophagoscope was inserted into introitus, the denture was seen at $20 \mathrm{~cm}$ from incisivus.

Under camera guided, acrylic part was seen, and then grasping forcep pull out it, simultaneous rigid esophagoscope was done too and succeeded. Afterthat lumen esophagus was assessed, rigid esophagoscope was inserted again. Laceration was presented at level $20 \mathrm{~cm}$ from incisivus at the right side but active bleeding was not found. Nasogastrictube (NGT) no 16 was inserted. Esophagoscopy was finished.

Patient was hospitalized with therapy ceftriaxone inj $2 \times 1$ gram, dexamethasone inj $3 \times 5 \mathrm{mg}$, ranitidine inj 2x1 amp, liquid diet through NGT. Patient was asked to do not feeding and drinking into mouth and not swallowing the saliva during NGT was in.
One day post operation the general condition was good, compos- mentis cooperative. Fever and difficulty in breathing were not found. Pain in swallowing was not presented. Nasogastrictube was stand in and subcutaneus emphysema was not detected. Cervical radiograph was performed and subcutaneous emphysema was not found.

On second day, September $16^{\text {th }} 2010$ NGT was pulling out, before that drinking test was done. Patient was discharged on third day and therapy was substituted by cefixime liquid $2 \times 100 \mathrm{mg}$. Patient was asked to control to ENT outpatient clinic one week later. Patient was controlled one week after to ENT outpatient clinic, no fever and no pain in swallowing. In physical examination subcutaneous emphysema was not found, neither.

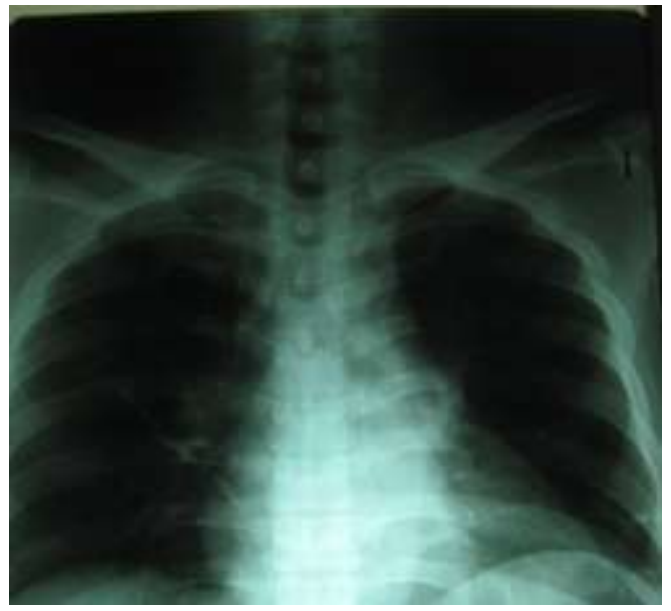

Fig.4. Cervicothorax anteroposterior radiograph on September, $15^{\text {th }} 2010$

\section{Discussion}

A 31 years-old man was diagnosed by foreign body denture in esophagus was reported. Miyazaki ${ }^{8}$ recorded foreign body in esophagus in adult, swallowed denture was in fourth ranking, it was $17 \%$, then third, second and first were sequentially fishbone $18 \%$, press-through packages $23 \%$, foodbolus impacted $34 \%$. Fang ${ }^{9}$ et al reported from 2008 through 2009, six patients with esophageal impacted denture were treated in their department on an emergency basis. There were four men (66.7\%) and two women (33.3\%) ranging in age from 40 to 76 years.

The other author mentioned that fifty seven patients with foreign body in esophagus, twenty-two adults had impacted esophageal acrylic dentures of which sixteen $(72.7 \%)$ and six $(27.3 \%)$ were males and females, respectively (M:F ratio $=2.7: 1$ ) with age range between 23-77 years. ${ }^{1}$ Nwafo ${ }^{1}$ et al was cited by Nwaorgu reported a male : female ratio of $2: 1$, while on the case report of Lavine and Stoopack stated that a male was more incidence than female.

Impacted denture in this case was replacing from the upper incisivus numerous one. Nwaorgu found $40.9 \%$ upper dentures and $13.6 \%$ lower denture at swallowed dentures case.

Phillipps ${ }^{1}$ et al and Okeowo cited by Nwaorgu found no significant association between the incidence of wearing and impaction of dentures in age-matched population. Nwaorgu ${ }^{1}$ findings are in agreement with the impressions of Phillipps et al and Okeowo that 
misfortune, carelessness through people bolting/hurrying over their food, and ignorance are the main reasons for ingesting foreign bodies. In this case, the patient's age is 31 years old.

Patient came with pain and difficulty in swallowing and excessive salivation in throat. The main symptoms of patients complain were difficulty in swallowing, acute onset of pain, dysphagia and excessive salivation. ${ }^{4,9}$ Singhals $^{10}$ reveals that dysphagia (92\%) and tenderness in neck $(60 \%)$ are the most common clinical features.

Ritcliff ${ }^{5}$ described symptoms associated with esophageal foreign body impaction are listed in table 1.

Table 1. Incidence of Symptoms in Esophageal Foreign Body ${ }^{5}$

\begin{tabular}{ll}
\hline Symptom & $\begin{array}{l}\text { Incidence } \\
(\%)\end{array}$ \\
\hline Dysphagia & 42 \\
Pain & 24 \\
Foreign body sensation & 21 \\
Regurgitation & 21 \\
Salivation & 19 \\
Gagging & 14 \\
Cough & 13 \\
Choking & 10 \\
Fever & 4 \\
No symptom & 18 \\
\hline
\end{tabular}

Nwaorgu ${ }^{1}$ reported twenty two cases impacted foreign body, $100 \%$ pain or discomfort in the throat, $81 \%$ foreign body sensation in the throat, $13.6 \%$ hoarseness, $13.6 \%$ fever, and $9.1 \%$ referred otalgia.

Physical examination may be normal in as many as $90 \%$ of patients with esophageal impaction. Rare findings on physical examination include fever, pharyngeal erythema, palatal abrasion, and subcutaneous emphysema suggestive of esophageal perforation. ${ }^{5}$ In the mean while Nwaorgu ${ }^{1}$ reveals neck tenderness $68.2 \%$, pooling of saliva in oro-pharynx $31.8 \%$ and neck swelling $4.5 \%$. In this patient echymosis at both of peritonsil and pooling saliva in oropharynx were presented.

Radiological finding in this case was found radioopaque at level cervical VI-VII. Lodgment of foreign body most commonly just below the cricopharyngeus and follow in the thoracic esophagus at the compression of the esophagus by the aortic arch or left bronchus or at a stricture. ${ }^{1,11}$ The diameter of the esophagus is reduced at four points: the cricopharyngeus, the crossing of the aorta at 25 to 30 $\mathrm{cm}$ from the incisors, the crossing of the left bronchus, and the hiatus at the diaphragm. ${ }^{12}$

Nwaorgu ${ }^{1}$ described a majority of the dentures fourteen $(63.6 \%)$ were impacted in the upper esophagus (between the cricopharyngeus and the thoracic inlet), while seven $(31.8 \%)$ and one $(4.5 \%)$ were impacted in the upper thorax and lower esophagus, respectively. The other author recorded that the entrapment of the foreign body was in the cervical esophagus in $57 \%$ of cases, in the thoracic one in $26 \%$ and at the cardioesophageal junction in $17 \%$ and the duration of impaction was less than $24 \mathrm{~h}$ in most cases. ${ }^{4}$ Eighty percent of the impacted foreign bodies are held up at the level of cricopharyngeus. ${ }^{13}$
In the mean while Singhal ${ }^{10}$ found postcricoids region is the site of impaction of foreign bodies in $84 \%$ of the subjects. Radiologic examination, Fang et.al reveals that location of the dentures was in the upper esophagus in three cases and in the thorax in two cases; in one case it was in the lower esophagus. ${ }^{9}$

Dentures are frequently made of acrylic resin, which is radiolucent, but the radioopaque wire clasps of the denture can some time be seen. ${ }^{9}$ If a radiolucent foreign body is suspected, swallowing studies with contrast medium should be performed. ${ }^{5}$ Location of stagnant is revealed the impaction. ${ }^{14}$ But barium may also covered the foreign body so it make the difficulty to esophagoscopy that will done. ${ }^{13,14}$ In this case there is part of radiopaque of denture so in radiological examine was showed.

In extraction of foreign body, choice of instrument is crucial factors. ${ }^{6}$ Rigid esophagoscope is technique commonly used to extract foreign body, with success rate $80 \%$. $^{3}$ The most commonly used method for removal of impacted foreign bodies in the esophagus is rigid endoscopy, which was described in 1937 by Jackson and Jackson. The rigid endoscope gives a better view of hypopharynx and upper cervical esophagus and also provides a more controlled situation for removal of sharp foreign bodies with improved visibility. It has been recommended that the rigid endoscope is used for foreign bodies lodged at the level of the hypopharynx and crico-pharyngeus, with the flexible endoscope being reserved for obstructions distal to this. ${ }^{7}$ In this patient the foreign body was impacted below cricopharynx level.

The other authors found $97 \%$ cases succeeded done by esophagoscope. ${ }^{10}$ In the mean while Weissberg ${ }^{6}$ described the succeeded rate rigid esophagoscope was $94 \%$ and $100 \%$. Athassiadi ${ }^{4}$ recorded rigid esophagoscope used by 343 cases (85.7\%) from 400 cases.

In the "high-low" technique described by Jackson, the position of both the endoscopist and the patient's head and neck relative to his body change as the endoscopy proceeds. Jackson divides the procedure into four stages: entering the right piriform sinus, passing the cricopharyngeus, passing through the thoracic esophagus, and passing through the hiatus. $^{12}$

Initially, to bring the cervical spine, and therefore the esophagus, into a straight line with the upper portion of the dorsal spine, the head is elevated into the "high" position. The endoscopist stands cephalad to the patient. Jackson asserted that the services of a trained assistant to place the head in the proper sequential "high-low" positions are indispensable; head position can also be maintained by flexing the neck joint of the operating room table or placing a firm support under the head. ${ }^{12}$

Initially, the esophagoscope is nearly vertical, with the long end of the bevel positioned anteriorly. As the esophagoscope is advanced along the right side of the tongue and down the posterior pharyngeal wall, the long bevel is used to lift the tongue base, endotracheal tube, and arytenoid cartilages in advance of the esophagoscope and the position of the esophagoscope will approach horizontal. To insert the esophagoscope in the midline, posterior to the arytenoids, required a degree of force dangerous to exert and almost certain to produce damage to the cricoarytenoid joint or to the pharyngeal wall, or to both. ${ }^{12}$ 
A lifting motion imparted to the tip of the esophagoscope by the left thumb will expose the rounded right arytenoid eminence. The tip of the esophagoscope should now be directed somewhat toward the midline, following the funnel shape of the hypopharynx. ${ }^{12}$

The endoscopist's right hand remains at the proximal end of the esophagoscope to control the angle of insertion and progression of the esophagoscope, as well as the position of the telescope within the esophagoscope, and to manipulate side channel suctions or other equipment. The endoscopist's left hand is positioned at the alveolar ridge or maxillary teeth. The fingers of the left hand advance the esophagoscope and maintain an awareness of a space between the esophagoscope and the patient's teeth, and the left thumb lifts the tip of the esophagoscope. The cricopharyngeus is entered without force. ${ }^{12}$

To prevent perforation the esophagoscope is to be passed only with ocular guidance. Once the esophagoscope is introduced through the esophageal introitus and cricopharyngeus, the endoscopist sits and the head of the operating table is lowered below horizontal. At this point, the esophagoscope can be rotated so that the side-channel port is on the right, facilitating passage of suction catheters or instruments with the endoscopist's right hand. While instruments are manipulated with the right hand, the left hand maintains the appropriate position of the esophagoscope. $^{12}$

The esophagoscope is gently advanced with the left hand, following the lumen. If the patient's position is correct, the esophagoscope should glide easily through the thoracic esophagus. ${ }^{12}$ Esophagoscopy pro-cedure in this case was like a Jackson technique.

Denture was successful removed in general anesthesia in this case. It is very important to know which foreign bodies in the esophagus are difficult to remove endoscopically. In general, pointed, sharp, and elongated foreign bodies can be very challenging and difficult to manage endoscopically. Long and sharp foreign bodies should be removed immediately before they pass from the stomach to the intestines because $15 \%-35 \%$ of them will cause intestinal perforation. In Miyazaki's study, foreign bodies that were difficult to remove on the first endoscopy were a long rubber tube and dental prostheses. Dental prostheses vary in shape, length, and material. Shimizu ${ }^{8}$ et al was cited by Miyazaki collected and analyzed 20 cases of esophageal foreign bodies caused by dental prostheses and reported that the size of the prostheses ranged from 2 to $6.5 \mathrm{~cm}, 65 \%$ were partial dentures, and the clasp of the partial denture, with a sharp tip, caused bowel perforation.

A large dental prosthesis should be removed under general anesthesia. Therefore, it is advisable to try removing such larger dental prostheses using a flexible or rigid endoscope first under general anesthesia. In this case esophagoscopy was performed in general anesthesia.

If esophagus perforation was presented extraction cannot be performed so require surgery intervention. 6,9

Upper dentures usually have larger surface areas than the lower dentures, which make them easier to extract. ${ }^{1}$ In this case patient swallowed upper denture that has larger surface area, so make it simple to pull out.

Successful in extraction require experience of operator, visibility of foreign body and choice of instrument. $^{8,9}$

Nwaorgu $^{1}$ described com-plication of operation based on the degree of mucosal injury varied from bruising of the esophageal mucosa which was noted in ten (45.5\%), erythema and inflammatory edema in seventeen (77.3\%), and laceration in two $(9.1 \%)$ patients. All mucosal injuries were successfully managed conservatively with NGT feeding, parenteral broad-spectrum antibiotics and analgesics within a week postoperatively. It was different manner of treatment in this case, the patient use NGT just two days post operation because laceration was minimal presented.

In this case foreign body was removed in 24 hour after impacted. Those with foreign bodies impacted for more than 24 hours were 14.1 times more likely than those with foreign bodies impacted for less than 24 hours to have a major complication. ${ }^{15}$ Some further delay may have resulted in the tooth eroding into the right common carotid artery. Esophageal perforation, if left untreated, carries a high mortality rate. In this case denture extraction was performed in 24 hours after impacted. ${ }^{16}$

Complication of rigid esophagoscope can minimilize when extraction performed in 24 hours after impaction. ${ }^{7}$ Shinghals reported $89 \%$ patient came to hospital in 24 hours. Complication in adult $18 \%$ was more than children $8.8 \%{ }^{10}$ It estimate esophagus perforation occur $0.34 \%$ with mortality $0.05 \%$. ${ }^{6,11}$

The other author is reported that the risks of esophageal perforation and mortality are 0.34 and $0.05 \%$ respectively using the rigid endoscope. ${ }^{7}$

$\mathrm{Lam}^{18}$ revealed incidence of esophagus perforation with rigid esophagoscope $0.2 \%-1.2 \%$. Perforation occurs most in the narrowest side of esophagus that is cricopharynx region or below. ${ }^{18}$ Endoscopic extraction of dentures carries a high risk of perforation. Factors responsible for this include the size, rigidity, sharp edges of the dentures, and attempting extraction in less-than-ideal situations. In addition to these, the degree of periesophagitis at the site of impaction may increase the risk of perforation. Thus, there is no room for expectant or conservative management in cases of impacted dentures, as the risk of complications increase the longer it takes before appropriate surgical intervention. Then it becomes imperative for the denture to be removed under direct vision as soon as a diagnosis is made. ${ }^{1}$

The natural history of an untreated impacted foreign body in the adult is poor, with complications such as esophageal perforation, mediastinitis, fistula formation and development of a pleural empyema resulting in mortality figures as high as $50 \%{ }^{7}$

Acrylic denture should be done by professional one and dentures should therefore be made of radiopaque material and supported well with metal wires. ${ }^{19}$ In this case there was radioopaque part of denture. In this patient, denture was done by teeth worker, not the dentist.

Some authors reported demonstrate the importance of radiodensity and mass of any aspirate of dental origin in regard to it being discovered on a chest radio-graph. ${ }^{14,19-21}$ In this case there was radioopaque part of denture. 
The increased aging of the population, the incidence of dental prostheses occurring as esophageal foreign bodies will likely increase in the future. It is therefore important for dentists and ancillary staff to educate elderly patients about the dangers of the accidental swallowing of dental prostheses and to pay attention to the stability of dental prostheses inside the oral cavity.

Patients should also be educated on the importance of adherence to instructions of mechanics of use, life span, maintenance of dentures, and maintenance recall visits to assess the retention of dentures. The use of fractured denture fragments and superglue to fix such dentures should be avoided. ${ }^{1}$

\section{References}

1. Nwaorgu OG, Onakoya PA, Sogebi OA Esophageal Impacted Dentures. Journal of National Medical Association 2004; 96: 1350-3

2. Adhikari P, Shrestha BL, Baskota DK. Accidental Foreign Body Ingestion: Analysis of 163 cases. Archive of otorhinolaryngology $2007 ; 11: 438-9$

3. Han S, Kayhan B, Dural K. A New and safe technique for removing cervical esophageal foreign body. Turk J Gastroenterol 2005; 16: 10810

4. Athassiadi K, Gerazounis M, Metaxas E. Management of Esophageal Foreign Bodies: a retrospective review of 400 cases. European Journal of Cardio-thoracic Surgery 2002; 21: 6536.

5. Ritcliff KM. Esophageal Foreign Body. American Family Physician 1994; 44: 824-31

6. Weissberg D, Refaely Y. Foreign Bodies in the Esophagus. Ann thorac Surg 2007; 84: 1854-7.

7. Balasubramaniam SK, Black MI, Salama NY, Mitchell DB. A review of the current management of impacted foreign bodies in the oesophagus in adults. Eur Arch Otorhinolaryngol 2008; 265 : 951 6.

8. Miyazaki T, Hokama N, Kubo N. Management of esophageal foreign body: experience of 90 cases. Esophagus $2009 ; 6: 155-9$.

9. Fang R, Sun J, Hu Y. Endoscopic Removal of Esophageal Impacted Dentures. Annals of Otology, Rhinology \& Laryngology 2010; 119: 249-51.

10. Singhal S. An Unusual Foreign Body in Esophagus. Online Journal of health and Allied Sciences India 2010; 9:1-2
11. Yang JY, Deutsch ES, Relly JS Broncoesophagology. In: Snow JB. Manual of Otorhinolaryngology Head and neck Surgery. London: Decker, 2002 : 546-61.

12. Yang JY, Deutsch ES, Reilly JS. Bronchoeophagology. In: Ballenger's Otorhinolaryngology Head and Neck Surgery. Spain: Decker, 2003 : 1578-88.

13. Akhtar N, Taqi M, Ibrahim E. Impaction of a Seed in the Esophagus. Professional Med J 2008; 15: 292-4.

14. Joshi SW, Pawar A, Lakhkar D. Denture in Esophagus Mimicking Carcinoma. Ind J Radiol Imag 2005; 15: 229-30

15. Loh KW, Tan LKS, Smith JD. Complications of foreign bodies in the esophagus. OtolaryngologyHead and Neck Surgery 2000; 123: 613-7

16. Sreetharan SS, Prepagaran N, Satwart S. Unusual migratory foreign body in the neck. Singapore Med J 2004; 45: 487-8

17. Roffman E, Jalisi S, Hybels R. Failed Extraction of a Sharp Esophageal Foreign Body with a Flexible Endoscope. Arch Otolaryngol Head Neck Surg 2002; 128: 1096-98

18. Lam HCK, Woo JKS, Hasselt CA. Esophageal perforation and neck abscess from ingested foreign bodies: Treatment abd Outcomes. Ear, Nose \& Throat Journal 2003;82: 786-94

19. Rathore PK, Raj A, Meher R. Prolonged foreign body impaction in the oesophagus. Singapore Med J 2009;50: 53-4

20. Cameron SM, Whitlock WL, Tabor MS. Foreign body aspiration in dentistry: a review. Avaliable from:http://jada.ada.org/cgi/content/abstract/127/8 11224. Accesed September 16, 2010.

21. Hashmi S, Walter J, Smith W. Swallowed partial dentures. JR Soc Med 2004; 97:72-5. 